\title{
EFFECT OF CLAY MINERALS ON EXTRACTABILITY OF HEAVY METALS AND SEWAGE SLUDGE MINERALIZATION IN SOIL
}

\author{
A. R. A. USMAN*, Y. KUZYAKOV and K. STAHR \\ Institute of Soil Science and Land Evaluation (310), University of Hohenheim, \\ D-70593 Stuttgart, Germany
}

(Received 2 December 2003; In final form 19 January 2004)

\begin{abstract}
An incubation experiment lasting $111 \mathrm{~d}$ was carried out to study the effect of the addition of three clay minerals (Nabentonite, Ca-bentonite, and zeolite) to soil derived from sewage sludge on water-extractable and exchangeable forms of four heavy metals $(\mathrm{Zn}, \mathrm{Cd}, \mathrm{Cu}$, and $\mathrm{Ni}$ ), as well as on soil organic matter mineralization, microbial biomass $\mathrm{C}$ and the release of inorganic $\mathrm{N}$. The addition of clay minerals led to a significant decrease in waterextractable and exchangeable forms of heavy metals. The extent of decrease ranged from 14 to $75 \%$ for the water-extractable heavy metals and from 12 to $42 \%$ for the exchangeable form over the incubation time, as compared with untreated soil. The reduction in extractability of heavy metals was greater due to the addition of Na-bentonite and Ca-bentonite than that due to the addition of zeolite. Addition of clay minerals did not affect any of the following microbiological parameters in the soil: microbial biomass $\mathrm{C}$, organic $\mathrm{C}\left(\mathrm{C}_{\mathrm{org}}\right)$ mineralization, and metabolic quotient $\left(\mathrm{qCO}_{2}\right)$, and release of inorganic $\mathrm{N}$ during the first 3 weeks of incubation. However, as the incubation period increased, these parameters were positively changed by the addition of clay minerals, especially by the addition of Na-bentonite and Ca-bentonite. This result is explained by a strong reduction in extractability of heavy metals after the addition of Na-bentonite and Ca-bentonite.
\end{abstract}

Keywords: Clay minerals; Heavy metals; Organic matter mineralization; Microbial biomass C; Metabolic quotient; Inorganic N

\section{INTRODUCTION}

Agricultural use of sewage sludge has been common practice in waste disposal in recent decades. However, this practice is generally associated with the problem of heavy-metal accumulation in soils. It has been demonstrated in many studies that heavy metals adversely affect biological and biochemical functions in soil (Fließbach et al., 1994; Kandeler et al., 1996; Kelly and Tate III, 1998). Heavy metals introduced with compost or sewage sludge caused the accumulation of soil organic matter (SOM) and decreased the turnover rate of organic matter, because of inhibitory effects on microbial biomass (Chander et al., 1995; Leita et al., 1995). Chander and Brookes (1991) also found lower biomass and higher $\mathrm{qCO}_{2}$ values in heavy-metal-contaminated soils than in uncontaminated soils. The toxicity of heavy metals depends mainly on their bioavailability, and therefore on their chemical

*Corresponding author. Tel.: +49-711-459-3338; Fax: +49-711-459-3117; E-mail: adel@uni-hohenheim.de 
forms in both organic and inorganic matrices (Leita et al., 1999). When $\mathrm{Zn}$ and $\mathrm{Cu}$ were present together in the soils, the increase in bioavailability of $\mathrm{Zn}$ above $123 \mu \mathrm{g} \mathrm{g}^{-1}$ soil and $\mathrm{Cu}$ above $3.0 \mu \mathrm{g} \mathrm{g}^{-1}$ soil caused marked decreases in the amounts of soil microbial biomass (Chander and Brookes, 1993). Reduction of the solubility and bioavailability of heavy metals in contaminated soils without removing them from the soil is commonly carried out to reduce the negative impacts on the environment and improve the quality of contaminated soils. Therefore, the study focused on reducing the availability of heavy metals and thus its effect on some of the parameters related to microbial activity.

Welp (1999) reported that the sorption and immobilization of toxic metals in soil is an effective detoxification process and thus an essential part of the buffer capacity of soil. Immobilization of heavy metals caused an increase in basal respiration, litter decomposition and microbial activity (Kiikilä et al., 2001). There are several methods for immobilization of heavy metals in soil. Immobilization can be carried out by adding natural and synthetic chemical additives such as alkaline materials, phosphate minerals, iron and manganese oxides, aluminosilicates or coal fly ashes (Mench et al., 1998). Clay minerals are among the major materials that interact with almost all soil contaminants (Prost and Yaron, 2001). The adsorption of $\mathrm{Ni}, \mathrm{Cd}, \mathrm{Zn}$, and $\mathrm{Pb}$ by montmorillonite was reported by Schulthess and Huang (1990). Immobilization of heavy metals by natural zeolite (clinoptilolite) and six synthetic zeolites was studied by Oste et al. (2002), who found that the synthetic zeolites had an effect on immobilization of $\mathrm{Cd}$ and $\mathrm{Zn}$, but the amount of metals bound to the natural zeolite (clinoptilolite) is almost negliglible.

Therefore, our first aim was to compare three clay minerals, Na-bentonite, Ca-bentonite, and zeolite, in their ability to reduce the bioavailabilty of heavy metals $(\mathrm{Zn}, \mathrm{Cd}, \mathrm{Cu}$ and $\mathrm{Ni})$. In most studies investigating the effect of addition of different substances reducing the availability of heavy metals, only the heavy-metal concentration in different solutions and soil materials was investigated. The effect of addition on biochemical parameters was not investigated. As shown above, the reduction in extractability of heavy metals may help to improve the biochemical parameters. Therefore, the second aim was to monitor the changes in $\mathrm{C}_{\text {org }}$ mineralization (as $\mathrm{CO}_{2}$ evolution), inorganic $\mathrm{N}$, microbial biomass $\mathrm{C}$ and metabolic quotient $\left(\mathrm{qCO}_{2}\right)$ during the incubation of soil derived from sewage sludge with and without the addition of natural clay minerals. Our hypothesis was that the heavy-metal-polluted soil can be ameliorated by adding clay minerals, and this could find future use in plant production.

\section{MATERIALS AND METHODS}

\subsection{Soil and Treatments}

Soil samples were collected from a sewage sludge deposit area located $15 \mathrm{~km}$ north-east of Stuttgart. According to the FAO-UNESCO (1997) system, the soil type is an Urbic Anthrosol. The German name for this soil type is a 'Reduktosol' (Lehmann et al., 2000). X-ray diffraction analysis to determine the soil clay minerals was performed using a Siemens Instrument (D-500) with $\mathrm{Cu}-\mathrm{K} \alpha$ radiation (Zarei et al., 2001). In the clay fraction, poorly crystalline clay minerals of kaolinite, illite and vermiculite/smectite were detected. The soil samples were taken from the $15-$ to $35-\mathrm{cm}$ layer, corresponding to the $\mathrm{Ah} 2$ horizon. This soil had a high content of $\mathrm{C}_{\text {org }}$ and $\mathrm{CaCO}_{3}$ and a very high content of heavy metals (Tab. I). The soil was air-dried and sieved to pass through a 2-mm sieve before the experiment and chemical analysis.

Three clay minerals of Na-bentonite, Ca-bentonite and zeolite (Fa. IKO Minerals GmbH, 45772 Marl) were used as additives to the soil as treatments. Na-bentonite and Ca-bentonite 
TABLE I Physico-chemical properties of soil derived from sewage sludge.

\begin{tabular}{lr}
\hline Properties & Value \\
\hline Particle size distribution (\%) & \\
Sand & 42 \\
Silt & 40 \\
Clay & 18 \\
Chemical properties & \\
$\mathrm{pH}$ & 7.0 \\
$\mathrm{CaCO}(\%)$ & 8.9 \\
Organic C (\%) & 13.3 \\
Total N (\%) & 1.7 \\
Total heavy-metal content $\left(\mathrm{mg} \mathrm{kg}^{-1}\right)$ & 4500 \\
$\mathrm{Zn}$ & 77 \\
$\mathrm{Cd}$ & 2000 \\
$\mathrm{Cu}$ & 442 \\
$\mathrm{Ni}$ & \\
\hline
\end{tabular}

used in this study are composed of clay minerals of the smectites group, mostly montmorillonite $(62-70 \%)$. Ca-bentonite with smectites that are predominantly occupied with $\mathrm{Ca}^{2+}$ ions originated from Bavarian mines. Na-bentonite with smectites whose initial composition of alkaline-earth cations has been replaced with $\mathrm{Na}$ ions in a technical process (alkali activation). Clinoptilolite (zeolite) is the most abundant naturally occurring zeolite consisting of hydrated aluminosilicate with alkali and alkaline earth cations in a three-dimensional crystal structure. Zeolite is composed of clay minerals of clinoptilolite (80\%), montmorillonite (10\%) and feldspar $(5 \%)$. Each clay mineral $(0.5 \mathrm{~g})$ was added to $25 \mathrm{~g}$ of soil. The soil-clay mineral mixtures were put into glass vessels $(250 \mathrm{ml})$. Distilled water was added to each soil mixture to bring it to $70 \%$ of water-holding capacity (WHC). A soil without addition of clay minerals was incubated as the control. Small vials with $5 \mathrm{ml}$ of $1 \mathrm{M} \mathrm{NaOH}$ solution were placed in vessels to trap $\mathrm{CO}_{2}$. The $\mathrm{NaOH}$ solution in the vials was changed after 10, 15, 21, 30, 39, 45, 54, 62, 74, 83, 95 and $111 \mathrm{~d}$. After the addition of $\mathrm{NaOH}$, the vessels were closed air-tight and incubated $111 \mathrm{~d}$ at $35^{\circ} \mathrm{C}$. This temperature was chosen, because the optimal temperature for microbial activity ranges from 20 to $35^{\circ} \mathrm{C}$ (Scheffer and Schachtschabel, 2002).

\subsection{Analyses}

Soil $\mathrm{pH}$ was measured with a glass electrode using a soil-to- $0.01 \mathrm{M} \mathrm{CaCl}_{2}$ ratio of $1: 2.5$. Total soil $\mathrm{C}$ and $\mathrm{N}$ were measured using a LECO $2000 \mathrm{CN}$ analyser. The inorganic carbon was determined using a Scheibler apparatus (carbonates were dissolved with $10 \%$ $\mathrm{HCl}$, and the volume of released $\mathrm{CO}_{2}$ was measured). The carbonate concentrations were calculated using the universal gas law (Schlichting et al., 1995). Soil organic carbon was calculated as the difference between total carbon and inorganic carbon. The soil texture was determined by a pipette method (Schlichting et al., 1995). The total content of $\mathrm{Zn}, \mathrm{Cd}, \mathrm{Cu}$ and $\mathrm{Ni}$ was determined using an aqua regia microwave digestion method. Microwave digestion was performed using $10 \mathrm{ml}$ of aqua regia with a nine-stage program; the microwave power ranged from 0 to $750 \mathrm{~W}$, the temperature ranged from 70 to $105^{\circ} \mathrm{C}$, and the digestion time was $30 \mathrm{~min}$. Heavy-metal concentrations were determined by atomic absorption spectrometry (AAS Perkin Elmer 3100).

After 21,62 and $111 \mathrm{~d}$ of incubation, the soil was destructively sampled, and concentrations of water-soluble $\mathrm{Zn}, \mathrm{Cd}, \mathrm{Cu}$ and $\mathrm{Ni}$ were measured after extracting $2 \mathrm{~g}$ of air-dried soil with $50 \mathrm{ml}$ of $\mathrm{H}_{2} \mathrm{O}$ for $2 \mathrm{~h}$. After the water extraction, the soil sediment was extracted 
with $50 \mathrm{ml}$ of $1 \mathrm{M} \mathrm{NH}_{4} \mathrm{NO}_{3}$ for $2 \mathrm{~h}$ to estimate the exchangeable amounts of heavy metals (Schlichting et al., 1995). The heavy-metal content in the filtered solution was analysed by AAS.

Soil microbial biomass $\mathrm{C}$ was measured after 21, 62 and $111 \mathrm{~d}$ using a fumigationextraction method (Vance et al., 1987). In this technique, three replicates of each treatment were fumigated with ethanol-free chloroform for $24 \mathrm{~h}$ at $25{ }^{\circ} \mathrm{C}$. The soil samples were then extracted with $0.5 \mathrm{M} \mathrm{K}_{2} \mathrm{SO}_{4}$ for $30 \mathrm{~min}$. Three replicates of non-fumigated soil samples were extracted similarly. The extracted $\mathrm{C}$ was determined by dichromate oxidation at $100{ }^{\circ} \mathrm{C}\left(2 \mathrm{ml}\right.$ of extract $+1.5 \mathrm{ml}$ of $15 \mathrm{M} \mathrm{H}_{2} \mathrm{SO}_{4}+1.5 \mathrm{ml}$ of saturated aqueous solution of $\mathrm{K}_{2} \mathrm{Cr}_{2} \mathrm{O}_{7}$ ). The residual $\mathrm{K}_{2} \mathrm{Cr}_{2} \mathrm{O}_{7}$ was determined photometrically at $565 \mathrm{~nm}$ (Kuzyakov, 1997). The calibration of the extracted $C$ measurements was carried using glucose. Microbial biomass $\mathrm{C}$ was calculated as $E c / k_{\mathrm{EC}}$, where $E c$ is organic $\mathrm{C}$ extracted from fumigated soils minus organic $\mathrm{C}$ extracted from non-fumigated soils, and $k_{\mathrm{EC}}=0.45$ (Wu et al., 1990; Jörgensen, 1996).

$\mathrm{CO}_{2}$ evolved during the incubation was trapped in $1 \mathrm{M} \mathrm{NaOH}$, and the excess $\mathrm{NaOH}$ was titrated with $0.1 \mathrm{M} \mathrm{HCl}$ after addition of $\mathrm{BaCl}_{2}$ (Black, 1965). Total $\mathrm{C}_{\text {org }}$ mineralized was calculated as cumulative $\mathrm{CO}_{2}$ evolution (Leifeld et al., 2002). The specific respiration activity $\left(\mathrm{qCO}_{2}\right)$ was expressed as the production of $\mathrm{CO}_{2}-\mathrm{C}$ per unit biomass $\mathrm{C}$ and time (Anderson and Domsch, 1978).

Soil inorganic $\mathrm{N}\left(\mathrm{NH}_{4}-\mathrm{N}\right.$ and $\left.\mathrm{NO}_{3}-\mathrm{N}\right)$ in $0.02 \mathrm{M} \mathrm{CaCl}_{2}$ extracts (1 : 4 soil-to-solution ratio) from all treatments was determined using an autoanalyser (Fa. Scalar).

\subsection{Statistical Analysis}

Differences among treatments were tested by separate two-way ANOVAs and subsequent post-hoc comparisons of means (L.S.D. test, at $P=0.05$ ).

\section{RESULTS AND DISCUSSION}

\subsection{Dynamics of Water-Extractable and Exchangeable Forms of Heavy Metals in Soil Derived from Sewage Sludge Following Addition of Clay Minerals}

The water-extractable and exchangeable forms of heavy metals were redistributed to other forms by incubation and addition of clay minerals. For all the treatments, water-extractable $\mathrm{Cd}$ and $\mathrm{Ni}$ concentrations decreased significantly during the first 3 weeks of incubation (Fig. 1). In the untreated soil (control), water-extractable Cd decreased by 71, 66 and 33\% of initial content, and $\mathrm{Ni}$ decreased by 54, 70, and 58\%, after 21, 62 and $111 \mathrm{~d}$ of incubation, respectively. The reduction in water-extractable $\mathrm{Cd}$ and $\mathrm{Ni}$ concentrations can be explained by their retention by soil organic matter and calcium carbonate (El-Bassam and Stühmeier, 1978; Tyler and McBride, 1982; McBride et al., 2000). Sewage-sludge constituents also can lower $\mathrm{Cd}$ activity in soil solution via complexing by soluble ligands or colloidal surfaces (Bell et al., 1991). Villarroel et al. (1993) found that Cd in the saturation extracts of the sludge-treated soil was distributed among free ligand (38.7\%), chloride complexes $(8.4 \%)$, sulfate complexes (10.3\%) and organic complexes (38.7\%). Gray et al. (1998) reported that soil organic matter was important in controlling $\mathrm{Cd}$ sorption and desorption. It was observed that the rate of decrease in water-extractable $\mathrm{Cd}$ tended to decline as incubation progressed, but the reduction in water-extractable Ni fluctuated over the incubation time.

In contrast, water-extractable $\mathrm{Cu}$ in the untreated soil increased and changed little with time. The results showed that water-extractable $\mathrm{Cu}$ increased by about 12,24 and $3.8 \%$ of 

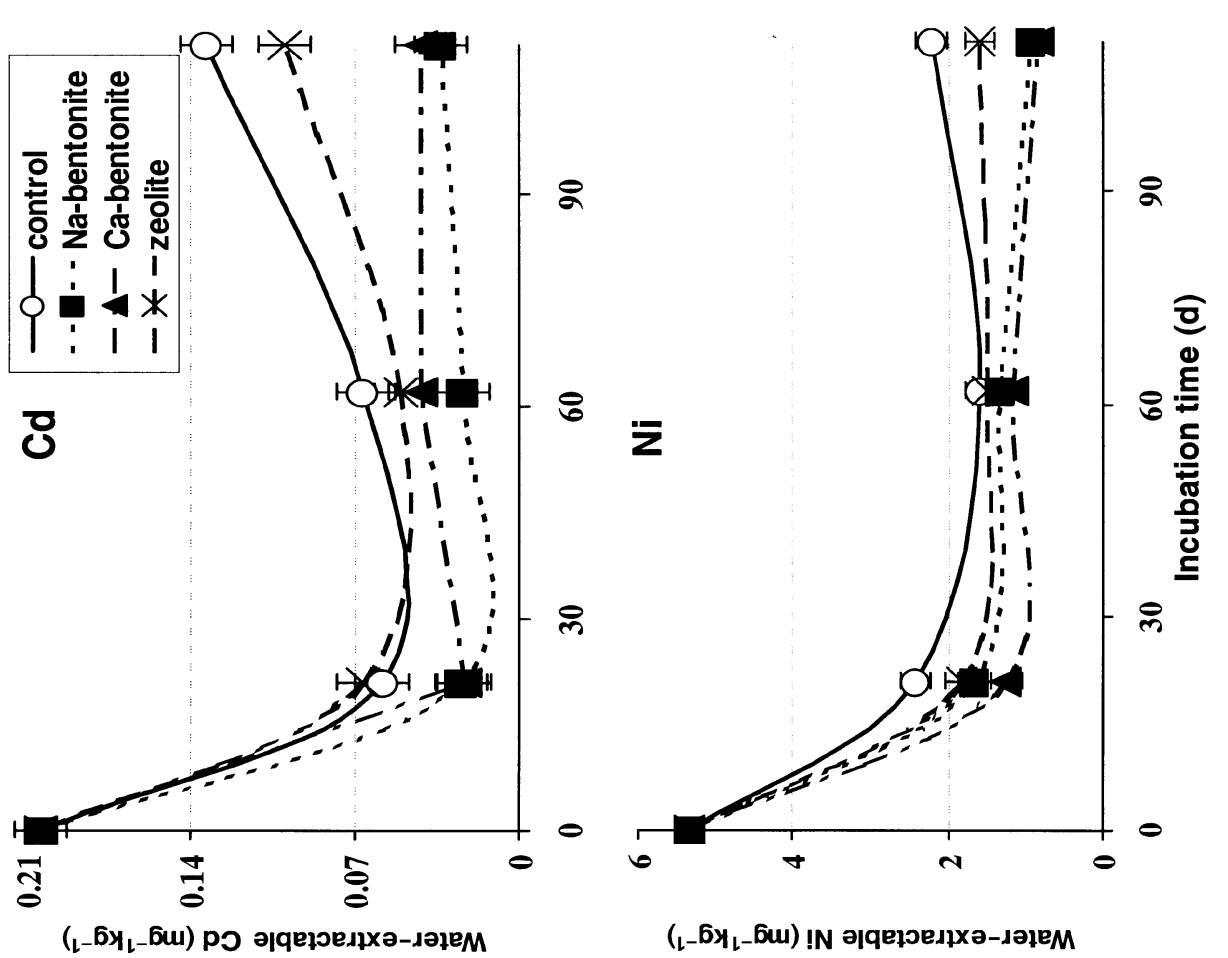

告

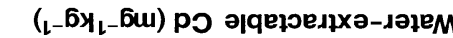

(
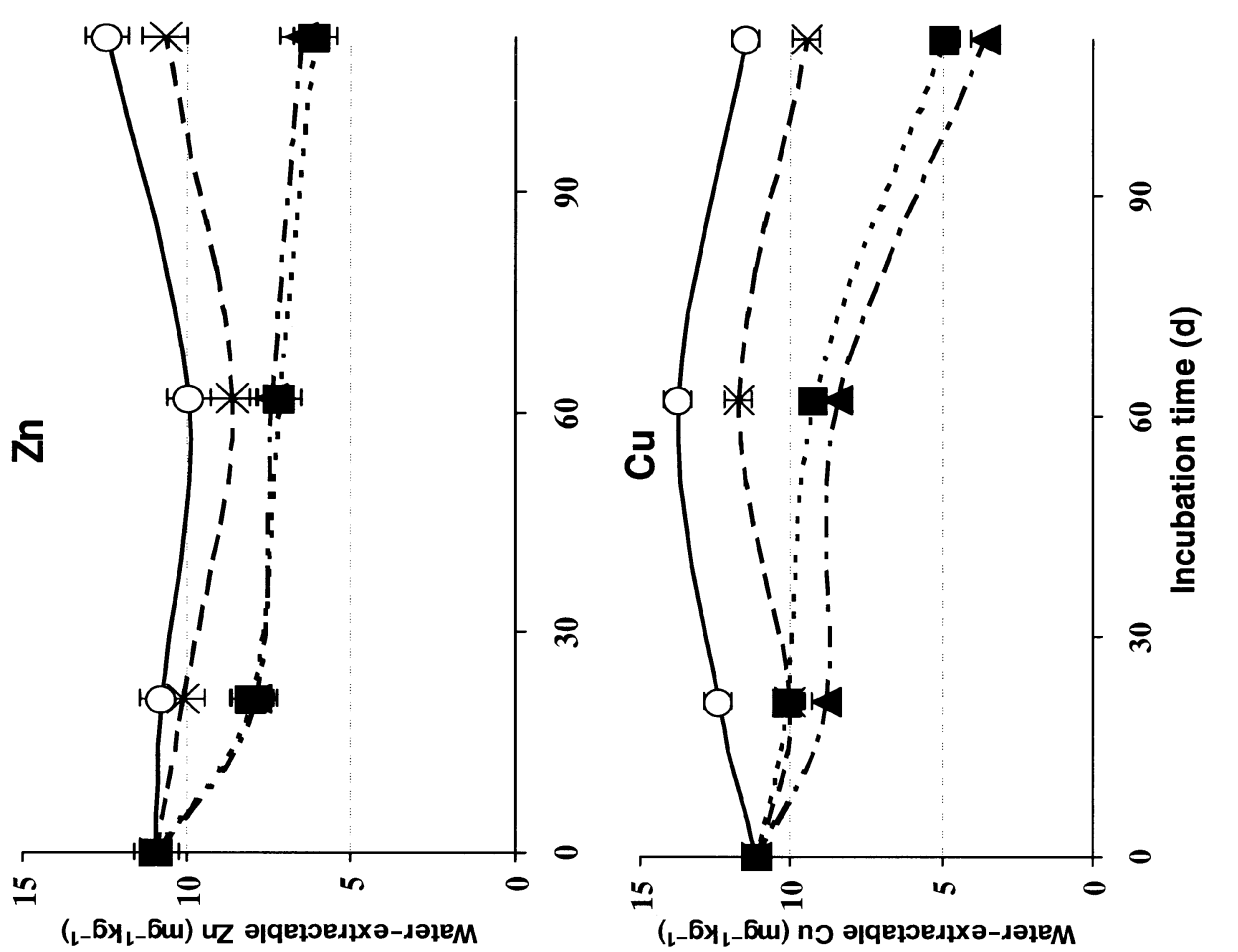
initial content after 21, 62 and $111 \mathrm{~d}$, respectively. Water-extractable Zn decreased by about $1.5 \%$ at $21 \mathrm{~d}$ and $9 \%$ at $62 \mathrm{~d}$ but increased by about $14 \%$ at $111 \mathrm{~d}$, as compared with initial soil, so it changed little with time. These increases in water-extractable $\mathrm{Zn}$ (at $111 \mathrm{~d}$ ) and $\mathrm{Cu}$ (at all sampling dates) may be explained by dissolved organic matter, which promoted the dissolution of $\mathrm{Cu}$ and $\mathrm{Zn}$ by building organic complexes. Almas et al. (2000) found that the addition of organic matter increased the solubility of $\mathrm{Zn}$ by the formation of organometallic complexes. In this study, it was observed that the increase in water-extractable $\mathrm{Cu}$ tended to decrease at the end of the incubation. This result is attributed to the tendency of soluble $\mathrm{Cu}$ to bind with organic matter or solid-phase materials. Organic matter in soluble and insoluble forms plays contrasting roles in controlling total soluble $\mathrm{Cu}$ and other metals as well. In sequential extractions of sludge-amended soils, $\mathrm{Cu}$ was found to predominate in the organic fraction (Sposito et al., 1982). Tyler and McBride (1982) found that $\mathrm{Cu}$ and $\mathrm{Ni}$ were less extractable from the organic soil than $\mathrm{Zn}$ and $\mathrm{Cd}$.

In all the treatments, incubation of soil derived from sewage sludge caused a decline in exchangeable form of all heavy metals tested (Fig. 2). As compared with initial soil, in untreated soil, the exchangeable form of heavy metals decreased by 21,26 and $27 \%$ for $\mathrm{Zn}$, by 38,36 and $32 \%$ for $\mathrm{Cd}$, by 23,22 and $29 \%$ for $\mathrm{Cu}$, and by 46,50 and $55 \%$ for $\mathrm{Ni}$ after 21,62 and $111 \mathrm{~d}$ of incubation, respectively. The results showed that the strongest reduction in the exchangeable form of all four heavy metals occurred during the first 3 weeks of incubation. After that, the reduction in exchangeable $\mathrm{Zn}, \mathrm{Cu}$ and $\mathrm{Ni}$ increased very little up to the end of the experiment. However, the rate of decrease in exchangeable $\mathrm{Cd}$ tended to decline slowly, as incubation progressed. A decrease in reduction in waterextractable and exchangeable $\mathrm{Cd}$ may be attributed to the formation of soluble $\mathrm{Cd}-$ organic associations over the time of incubation. Neal and Sposito (1986) found that soil sorption of $\mathrm{Cd}$ was reduced by the formation of soluble-organic associations in the aqueous solution. In our soil, the reduction in extractability of heavy metals is attributed, in part, to the neutral $\mathrm{pH}$, the presence of free calcium carbonate and, in part, the high organic matter content. This result concurs with that of McBride et al. (2000), who found that heavy metals were strongly retained in sewage sludge soil, which has a high organic matter and lime content. Ong and Bisque (1968) explained the phenomena of metal reduction by the fact that humic substances behave as negatively charged colloids, which may be coagulated by the electrolytes. Another phenomenon is that after the release of heavy metals from the sewage sludge, they react chemically with the soil so that metal toxicity declines with time (Lewin and Beckett, 1980).

The decrease in water-extractable and exchangeable forms of heavy metals in the soil treated with clay minerals was greater than without clay minerals. This effect was especially pronounced for the treatments with Na-bentonite and Ca-bentonite addition. For example, addition of clay minerals decreased water-extractable heavy metals at the end of the incubation as follows: $\mathrm{Zn}$ decreased by 51, 48 and 14\%, Cd by 75, 68 and 25\%, Cu by 57, 69 and 17 , and $\mathrm{Ni}$ by 59,63 and $29 \%$ at the end of the experiment for Na-bentonite, Ca-bentonite and zeolite, as compared with untreated soil, respectively. Na-bentonite and Ca-bentonite have a strong effect on the decrease in water-extractable heavy metals more than zeolite. This could be explained by high contents of the clay minerals in montmorillonite. Ca-bentonite and Na-bentonite are a higher proportion of montmorillonite $(62-70 \%)$ than for zeolite (10\%). The binding of $\mathrm{Ni}, \mathrm{Cd}, \mathrm{Zn}$ and $\mathrm{Pb}$ by montmorillonite was reported by Schulthess and Huang (1990).

In the soil treated with clay minerals, the exchangeable form of heavy metals decreased during the incubation. This decrease was relevant for $\mathrm{Cu}$, especially with Na-bentonite and Ca-bentonite after $111 \mathrm{~d}$ of incubation. After $21 \mathrm{~d}$ of incubation, exchangeable $\mathrm{Zn}$ was significantly affected by the addition of Na-bentonite and Ca-bentonite, but exchangeable $\mathrm{Ni}$ 


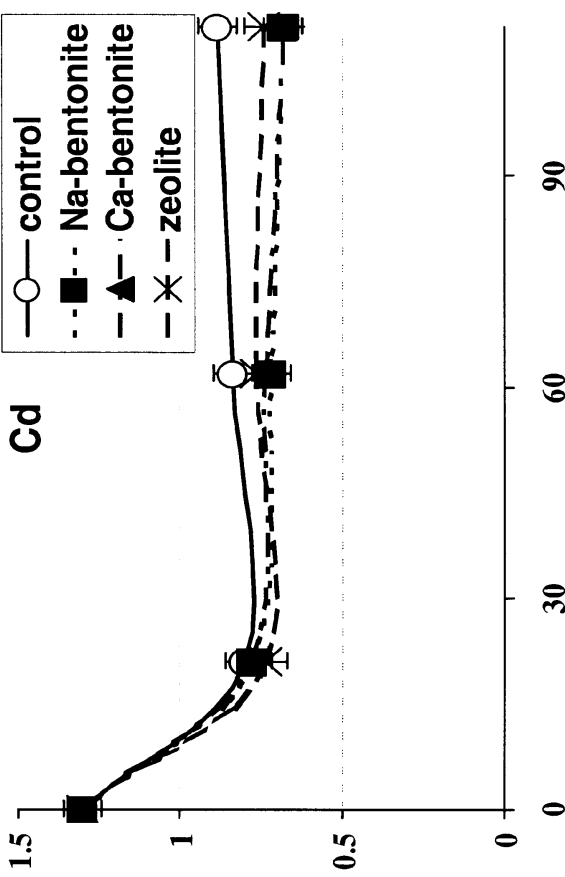

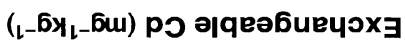
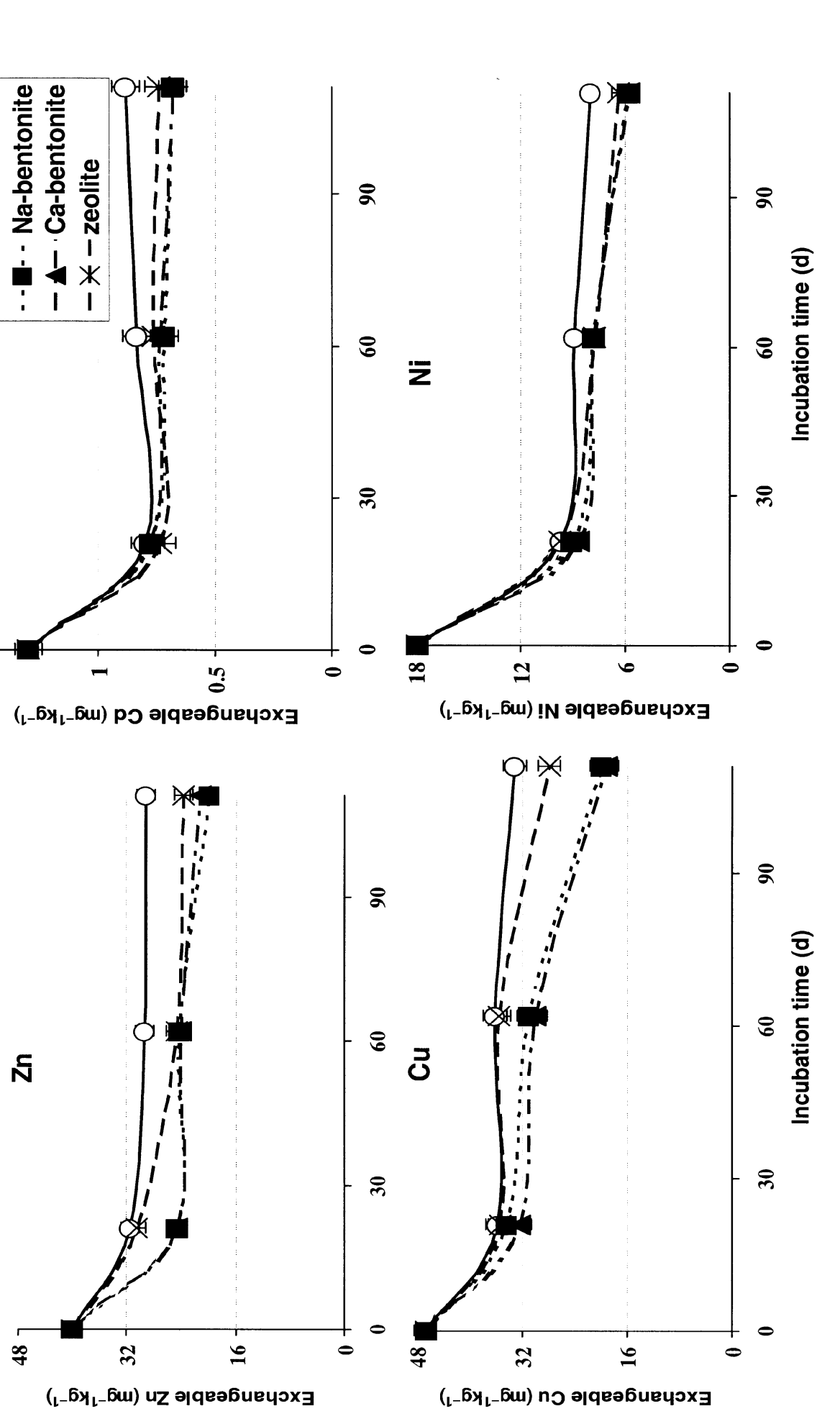

8

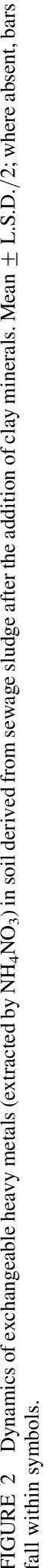


was significantly affected by the addition of Ca-bentonite. However, the amounts of exchangeable form of $\mathrm{Cu}$ and $\mathrm{Cd}$ were not significantly affected by the addition of clay minerals, as compared with untreated soil (control). At 62 and $111 \mathrm{~d}$ of incubation, addition of Ca-bentonite and Na-bentonite significantly decreased the amounts of exchangeable form of all four heavy metals, as compared with untreated soil (control). The addition of zeolite caused a significant reduction in the exchangeable form of $\mathrm{Zn}$ and $\mathrm{Ni}$ at 62 and $111 \mathrm{~d}$ but only resulted in a significant reduction in the exchangeable form of $\mathrm{Cu}$ and $\mathrm{Cd}$ at the end of the experiment, as compared with untreated soil (control). It was observed that the exchangeable form of heavy metals was significantly affected by the three added clay minerals. Compared with the untreated soil, the addition of clay minerals decreased the exchangeable $\mathrm{Zn}$ by 31, 27 and 19\%, Cd by 22, 23 and 16\%, Cu by 40, 42 and 16\%, and $\mathrm{Ni}$ by 27, 28 and $20 \%$ for Na-bentonite, Ca-bentonite and zeolite, as compared with untreated soil, respectively. There were no significant differences in the exchangeable forms of heavy metals between Na-bentonite and Ca-bentonite, but significant differences were found between the bentonites and zeolite for the exchangeable $\mathrm{Zn}$ and $\mathrm{Cu}$ during the incubation.

\subsection{Effect of Incubation Time and Addition of Clay Minerals on Organic C Mineralization, Microbial Biomass C, Metabolic Quotient and N Mineralization}

The $\mathrm{C}_{\text {org }}$ mineralization during the experiment was recorded as cumulative $\mathrm{CO}_{2}$ evolution. Numerous investigations have clearly demonstrated that inorganic colloids such as clays affect microbial biomass and turnover of soil organic matter (Martin et al., 1976; Ladd et al., 1985, 1992; Saggar et al., 1996; Nelson et al., 1997). The rate of decay of organic material is reduced by the presence of clay (Sørensen, 1975). In our investigation, cumulative $\mathrm{C}_{\text {org }}$ mineralization (as a percentage of intial $\mathrm{C}_{\text {org }}$ content) in soil derived from sewage sludge treated with clay minerals was higher than in untreated soil (control), especially for Ca-bentonite and Na-bentonite (Fig. 3). In the soil treated with clay minerals, $\mathrm{C}_{\text {org }}$ mineralization increased by about 12,9 and $2.6 \%$ for Ca-bentonite, Na-bentonite and zeolite compared with untreated soil, respectively.

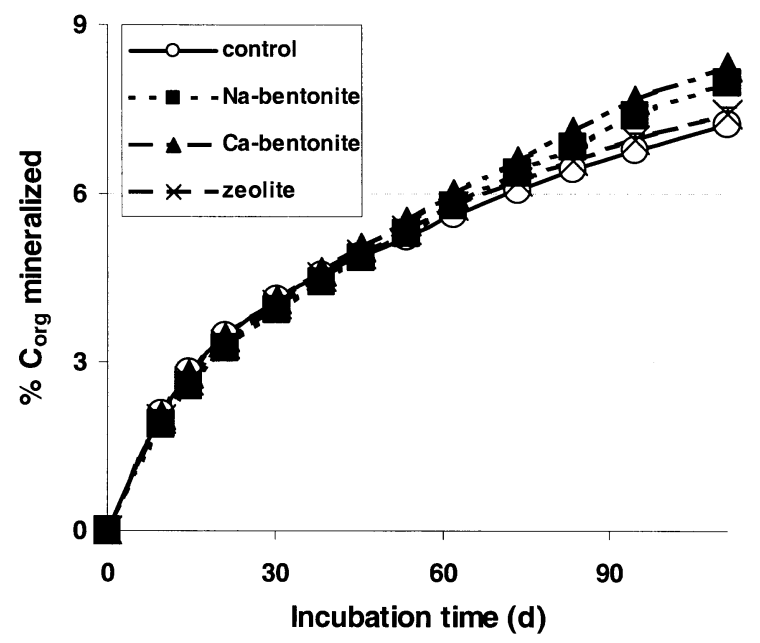

FIGURE 3 Effect of addition of clay minerals on cumulative organic $\mathrm{C}\left(\mathrm{C}_{\mathrm{org}}\right)$ mineralization during 111 days' incubation (as a percentage of initial $\mathrm{C}_{\text {org }}$ content). Mean \pm L.S.D. $/ 2$; where absent, bars fall within symbols. 
The soil microbial biomass was used as a sensitive indicator of changing soil conditions (Leita et al., 1999). The control soil initially contained about $16.2 \mathrm{mg}$ biomass $\mathrm{C} \mathrm{g}^{-1} \mathrm{C}_{\text {org }}$. For all treatments, microbial biomass $\mathrm{C}$ increased during the first 3 weeks of incubation, as compared with the initial soil. After day 21, microbial biomass $\mathrm{C}$ decreased with incubation time (Fig. 4). During the first 3 weeks of incubation, there were no significant differences in the effects of all treatments on the microbial biomass $\mathrm{C}$ levels. However, after 62 and $111 \mathrm{~d}$ of incubation, the addition of Ca-bentonite and Na-bentonite increased microbial biomass $\mathrm{C}$ significantly compared with untreated soil (control). Addition of zeolite increased microbial biomass $\mathrm{C}$ significantly only at the end of the incubation compared with untreated soil (control). It was observed that there were no significant effects on biomass $\mathrm{C}$ between $\mathrm{Ca}$-bentonite and $\mathrm{Na}$-bentonite, but significant differences were found between the clay minerals of bentonite and zeolite after 62 and $111 \mathrm{~d}$ of incubation. After $21 \mathrm{~d}$ of incubation, microbial biomass $\mathrm{C}$ values were 18.5 (control), 19.2 (with addition of Na-bentonite), 18.6 (with addition of Ca-bentonite) and $17.9 \mathrm{mg} \mathrm{g}^{-1} \mathrm{C}_{\text {org }}^{-1}$ (with addition of zeolite). At the end of the incubation $(111 \mathrm{~d})$, they were $6.7,14,15$ and $9 \mathrm{mg} \mathrm{g}^{-1} \mathrm{C}_{\text {org }}^{-1}$, respectively. At the end of the incubation, clay mineral application increased the microbial biomass $\mathrm{C}$ content in soil derived from sewage sludge about $53 \%$ for $\mathrm{Na}$-bentonite, $55 \%$ for $\mathrm{Ca}-$ bentonite and $28 \%$ for zeolite, as compared with untreated soil. Addition of clay mineral increased the microbial activity and then organic matter mineralization, because clay minerals reduced the availability of heavy metals to soil micro-organisms. This result concurs with Kiikilä et al. (2001), who reported that immobilization of heavy metals caused an increase in basal respiration, litter decomposition and microbial activity.

The metabolic quotient $\left(\mathrm{qCO}_{2}\right)$ is a relationship between soil respiration and microbial biomass $\mathrm{C}$ and is expressed as $\mathrm{mg} \mathrm{CO}_{2}-\mathrm{C} \mathrm{h}^{-1} \mu \mathrm{g}^{-1}$ biomass $\mathrm{C}$ (Anderson and Domsch, 1978). The $\mathrm{qCO}_{2}$ can be used as a marker of the environmental stress of the microbial population (Anderson and Domsch, 1993; Moreno et al., 1999). Our results showed that $\mathrm{qCO}_{2}$ was higher in untreated soil (control) than in soil treated with clay minerals as incubation progressed (Fig. 5). The higher values of $\mathrm{qCO}_{2}$ at the end of the experiment in the control were due to the lower values of microbial biomass $\mathrm{C}$ than in soil treated with clay minerals. The lower values of microbial biomass $\mathrm{C}$ and thus the higher values of the $\mathrm{qCO}_{2}$ found in the control at the end of the incubation are also related to the high availability of heavy metals (Leita et al., 1999).

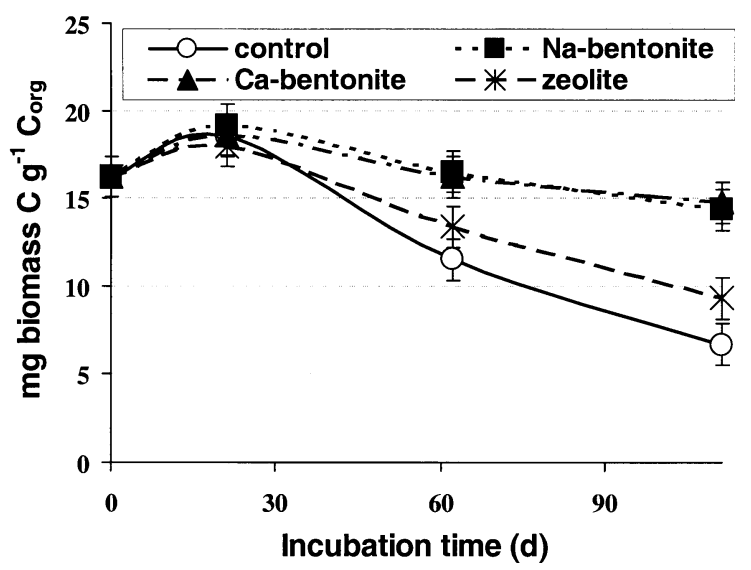

FIGURE 4 Changes in microbial biomass $\mathrm{C}$ in soil derived from sewage sludge after the addition of clay minerals. Mean \pm L.S.D. $/ 2$. 


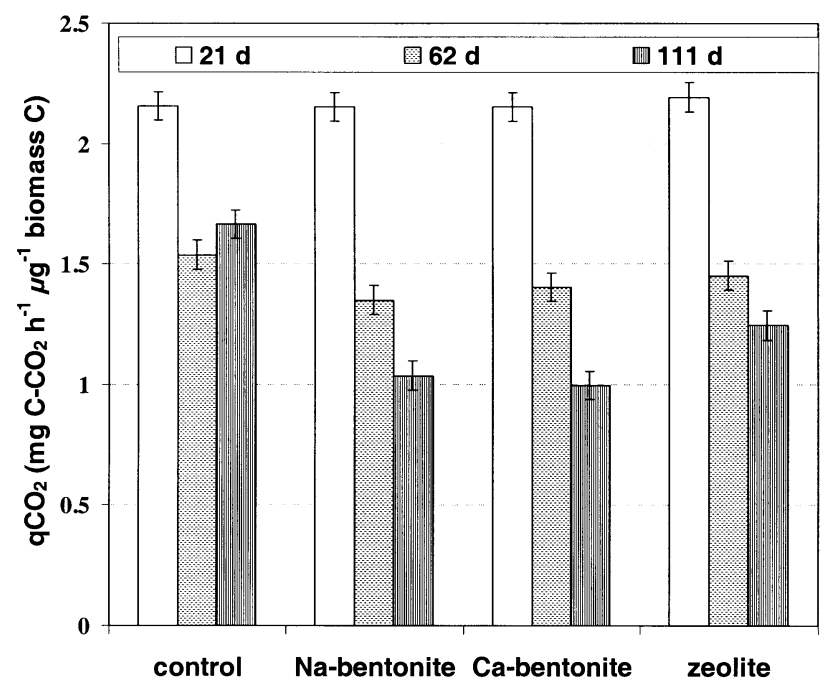

FIGURE 5 Changes in metabolic quotient $\left(\mathrm{qCO}_{2}\right)$ in soil derived from sewage sludge after the addition of clay minerals. Mean \pm L.S.D. $/ 2$.

The control soil initially contained $1.33 \mathrm{~g}$ inorganic $\mathrm{N} \mathrm{kg}^{-1}$ soil. In all the treatments, inorganic $\mathrm{N}$ was immobilized by micro-organisms during the first 3 weeks of incubation (Fig. 6), showing a high $\mathrm{C}$ availability. After this initial decline, the inorganic $\mathrm{N}$ content of all treatments began to increase steadily until the end of the experiment. During the $\mathrm{N}$ immobilization phase, no significant differences were found between any of the treatments in inorganic N. However, after $62 \mathrm{~d}$ of incubation, Ca-bentonite addition significantly increased the amounts of inorganic $\mathrm{N}$, as compared with untreated soil (control), and after $111 \mathrm{~d}$ of incubation, addition of Na-bentonite and Ca-bentonite significantly increased the amounts of inorganic $\mathrm{N}$ compared with untreated soil (control) and addition of zeolite. There were no significant differences in terms of the effects between addition of zeolite and untreated soil on inorganic $\mathrm{N}$. At the end of the incubation, the amounts of inorganic $\mathrm{N}$ increased by about 1.8, 2.2 and $0.35 \mathrm{~g} \mathrm{~N} \mathrm{~kg}^{-1}$ soil for Na-bentonite, Ca-bentonite and zeolite, respectively.

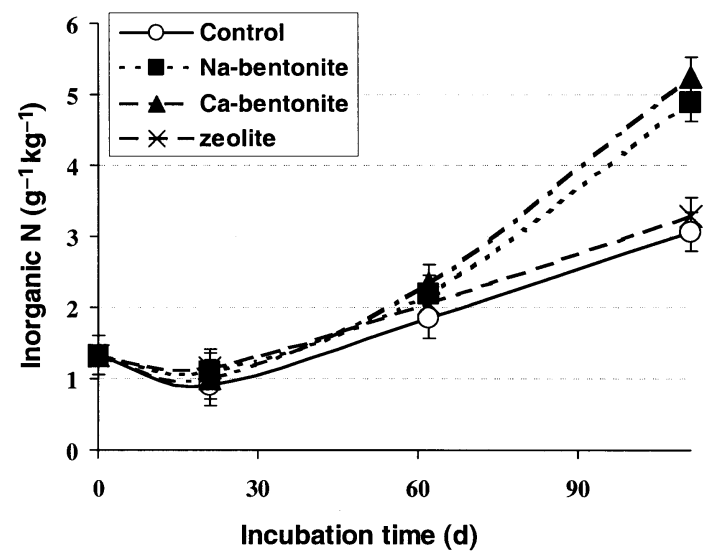

FIGURE 6 Changes in the amounts of inorganic $\mathrm{N}$ in soil derived from sewage sludge after the addition of clay minerals. Mean \pm L.S.D. $/ 2$. 
The availability of heavy metals in soil treated with Na-bentonite and Ca-bentonite was less than that in untreated soil and in soil treated with zeolite. This is related to higher amounts of inorganic $\mathrm{N}$ in soil treated with Na-bentonite and Ca-bentonite. $\mathrm{N}$ mineralization is very sensitive to heavy-metal pollution (Liang and Tabatabai, 1977, 1978).

\section{CONCLUSIONS}

The addition of clay minerals, especially of Na-bentonite and Ca-bentonite, decreased the extractability of heavy metals during incubation. After addition of Ca-bentonite and Na-bentonite to soil derived from sewage sludge, the decreased toxicity of heavy metals over the time of incubation was reflected as increased $\mathrm{C}_{\text {org }}$ mineralization, microbial biomass $\mathrm{C}$ and inorganic $\mathrm{N}$, and as a decreased metabolic quotient $\left(\mathrm{qCO}_{2}\right)$, as compared with untreated soil and addition of zeolite. The sensitivity of these parameters to a reduction in the extractability of heavy metals after addition of Na-bentonite and Ca-bentonite was as follows: microbial biomass $\mathrm{C}>\mathrm{qCO}_{2}>$ inorganic $\mathrm{N}>\mathrm{C}_{\text {org }}$ mineralization. The use of Na-bentonite and Ca-bentonite is a promising method for reducing the extractability and possibly the bioavailability of heavy metals in sewage-sludge-contaminated soil, and therefore for remediation of the soil.

\section{Acknowledgements}

The authors would like to thank S. Köhler for determination of inorganic N, K. Ruf for determination of total N, Dr A. Lehmann for soil information, Dr M. Zarei and D. Frobel for analysis of clay mineralogy, and A. Hardie for linguistic help. We are very thankful to Fa. IKO Minerals GmbH for the use of their bentonites and zeolite. This work was partly funded by the Egyptian government in the scope of fellowship for A. R. A. Usman.

\section{References}

Almas, A. R., McBride, M. B. and Singh, B. R. (2000). Solubility and lability of cadmium and zinc in two soils treated with organic matter. Soil Science, 165, 250-259.

Anderson, J. P. E. and Domsch, K. H. (1978). A physiological method for the quantitative measurement of microbial biomass in soil. Soil Biology and Biochemistry, 10, 215-221.

Anderson, T. and Domsch, K. H. (1993). The metabolic quotient for $\mathrm{CO}_{2}\left(\mathrm{qCO}_{2}\right)$ as a specific activity parameter to assess the effects of environmental conditions, such as $\mathrm{pH}$, on the microbial biomass of the soil. Soil Biology and Biochemistry, 25, 393-395.

Bell, P. F., James, B. R. and Chaney, R. L. (1991). Heavy metal extractability in long-term sewage sludge and metal salt-amended soils. Journal of Environmental Quality, 20, 481-486.

Black, C. A. (1965). Methods of soil analysis., American Society of Agronomy, Madison, WI.

Chander, K. and Brookes, P. C. (1991). Microbial biomass dynamics during the decomposition of glucose and maize in metal-contaminated and non-contaminated soils. Soil Biology and Biochemistry, 23, 917-925.

Chander, K. and Brookes, P. C. (1993). Residual effects of zinc, copper and nickel in sewage sludge on microbial biomass in a sandy loam. Soil Biology and Biochemistry, 25, 1231-1239.

Chander, K., Brookes, P. C. and Harding, S. A. (1995). Microbial biomass dynamic following addition of metalenriched sewage sludge to a sandy loam. Soil Biology and Biochemistry, 27, 1409-1421.

El-Bassam, N. and Stühmeier, K. (1978). Immobilisierung einiger spuren- und schadelemente durch zufuhr organischer siedlungsabfälle. Mitteilungen der Deutschen Bodenkundlichen Gesellschaft, 27, 221-230.

FAO-UNESCO (1997). Soil map of the world, revised legend, with corrections, World Resources Report 60, FAO, Rome, [Reprinted as Technical Paper 20. International Soil Reference and Information Center, Wageningen.].

Fließbach, A., Martens, R. and Reber, H. H. (1994). Soil microbial biomass and microbial activity in soil treated with heavy metal contaminated sewage sludge. Soil Biology and Biochemistry, 26, 1201-1205.

Gray, C. W., McLaren, R. G., Roberts, A. H. C. and Condorn, L. M. (1998). Sorption and desorption of cadmium from some new zealand soils: Effect of pH and contact time. Australian Journal of Soil Research, 36, 199-216. 
Jörgensen, R. G. (1996). The fumigation-extraction method to estimate soil microbial biomass: Calibration of the $k_{\mathrm{EC}}$ value. Soil Biology and Biochemistry, 28, 25-31.

Kandeler, E., Kampichler, C. and Horak, O. (1996). Influence of heavy metals on the functional diversity of soil microbial communities. Biology and Fertility of Soils, 23, 299-306.

Kelly, J. J. and Tate, R. L., III (1998). Effects of heavy metals contamination and remediation on soil microbial communities in the vicinity of a zinc smelter. Journal of Environmental Quality, 27, 609-617.

Kiikilä, O., Perkiömäki, J., Barnette, M., Derome, J., Pennanen, T., Tulisalo, E. and Fritze, H. (2001). In situ bioremediation through mulching of soil polluted by a copper-nickel smelter. Journal of Environmental Quality, 30, 1134-1143.

Kuzyakov, Y. V. (1997). The role of amino acids and nucleic bases in turnover of nitrogen and carbon in soil humic fractions. European Journal of Soil Science, 48, 121-130.

Ladd, J. N., Amato, M. and Oades, J. M. (1985). Decomposition of plant material in australian soils. III. Residual organic and microbial biomass $\mathrm{C}$ and $\mathrm{N}$ form isotope-labelled plant material and soil organic matter decomposition under field conditions. Australian Journal of Soil Research, 23, 603-611.

Ladd, J. N., Jocteur-Monrozier, L. and Amato, M. (1992). Carbon turnover and nitrogen transformation in an alfisol and vertisol amended with $\left[\mathrm{U}_{-}{ }^{14} \mathrm{C}\right]$ glucose and $\left[{ }^{15} \mathrm{~N}\right]$ ammonium sulphate. Soil Biology and Biochemistry, 24, $359-371$.

Lehmann, A. E. H., Holland, K. and Stahr, K. (2000). Flows and chemical fractions in a soil from sewage sludge. Zeitschrift für Kulturtechnik und Landentwicklung, 41, 206-210.

Leifeld, J., Siebert, S. and Kögel-Knabner, I. (2002). Biological activity and organic matter mineralization of soil amended with biowaste composts. Journal of Plant Nutrition and Soil Science, 165, 151-159.

Leita, L., De Nobili, M., Muhlbachova, G., Mondini, C., Marchiol, L. and Zerbi, G. (1995). Bioavailability and effects of heavy metals on soil microbial biomass survival during laboratory incubation. Biology and Fertility of Soils, 19, 103-108.

Leita, L., Nobili, M. D. and Mondini, C. (1999). Influence of inorganic and organic fertilization on soil microbial biomass, metabolic quotient and heavy metal bioavailability. Biology and Fertility of Soils, 28, 371-376.

Lewin, V. H. and Beckett, P. H. T. (1980). Monitoring heavy metal accumulation in agricultural soils treated with sewage sludge. Effluent and Water Treatment Journal, 20, 217-221.

Liang, C. N. and Tabatabai, M. A. (1977). Effects of trace elements on nitrogen mineralization in soils. Environmental Pollution, 12, 141-147.

Liang, C. N. and Tabatabai, M. A. (1978). Effects of trace elements on nitrification in soils. Journal of Environmental Quality, 7, 291-293.

McBride, M., Martinetz, C. E., Topp, E. and Evans, L. (2000). Trace metal solubility and speciation in a calcareous soil 18 years after no-till sludge application. Soil Science, 165, 646-656.

Martin, J. P., Filip, Z. and Haider, K. (1976). Effect of montmorillonite and humate on growth and metabolic activity of some actinomycetes. Soil Biology and Biochemistry, 8, 409-413.

Mench, M., Vangroensveld, J., Lepp, N. M. and Edwards, R. (1998). Physico-chemical aspects and efficiency of trace element immobilization by soil amendments, in Vangroensveld, J. and Cummingham, S. D. (eds.), Metalcontaminated soils: In situ inactivation and phytorestoration., Springer and R. G. Landes, Berlin, pp. 151-182.

Moreno, J. L., Hernandez, T. and Garcia, C. (1999). Effects of a cadmium-contaminated sewage sludge compost on dynamics of organic matter and microbial activity in an arid soil. Biology and Fertility of Soils, 28, $230-237$.

Neal, R. H. and Sposito, G. (1986). Effects of soluble organic matter and sewage sludge amendments on cd sorption by soils at low cadmium concentrations. Soil Science, 142, 164-172.

Nelson, P. N., Barzegar, A. R. and Oades, J. M. (1997). Sodicity and clay type: Influence on decomposition of added organic matter. Soil Science Society of America Journal, 61, 1052-1057.

Ong, H. and Bisque, R. E. (1968). Coagulation of humic colloids by metal ions. Soil Science, 106, 220-224.

Oste, L. A., Lexmond, T. M. and Van Riemsdijk, W. H. (2002). Metal immobilization in soils using synthetic zeolites. Journal of Environmental Quality, 31, 813-821.

Prost, R. and Yaron, B. (2001) Use of modified clays for controlling soil environmental quality. Social Science, 166, $880-894$.

Saggar, S., Parshotam, A., Sparling, G. P., Feltham, C. W. and Hart, P. B. S. (1996). ${ }^{14}$ C-labelled ryegrass turnover and residence time in soils varying in clay content and mineralogy. Soil Biology and Biochemistry, 28, $1677-$ 1686.

Scheffer, F. and Schachtschabel, P. (2002). Lehrbuch der Bodenkunde. 15. Auflage., Spektrum Akademischer, Heidelberg.

Schlichting, E., Blume, H. P. and Stahr, K. (1995). Bodenkundliches Praktikum, 2nd ed., Blackwell, Berlin.

Schulthess, C. P. and Huang, C. P. (1990). Adsorption of heavy metals by silicon and aluminum oxide surfaces on clay minerals. Soil Science Society of America Journal, 54, 679-688.

Sørensen, L. H. (1975). The influence of clay on the rate of decay of amino acid metabolites synthesized in soil during decomposition of cellulose. Soil Biology and Biochemistry, 7, 171-177.

Sposito, G., Lund, L. J. and Chang, A. C. (1982). Trace metal chemistry in arid-zone field soils amended with sewage sludge: I. Fractionation of ni, cu, zn, cd, and pb in solid phases. Soil Science Society of America Journal, 46, $260-264$

Tyler, L. D. and McBride, M. B. (1982). Mobility and extractability of cadmium, copper, nickle, and zinc in organic and mineral soil columns. Soil Science, 134, 198-205. 
Vance, E. D., Brookes, P. C. and Jenkinson, D. S. (1987). An extraction method for measuring microbial biomass C. Soil Biology and Biochemistry, 19, 703-707.

Villarroel, J. R., Chang, A. C. and Amrhein, C. (1993). Cd and zn phytoavailability of a field-stabilized sludgetreated soil. Soil Science, 155, 197-205.

Welp, G. (1999). Inhibitory effects of the total and water-soluble concentrations of nine different metals on the dehydrogenase activity of a loess soil. Biology and Fertility of Soils, 30, 132-139.

Wu, J., Jörgensen, R. G., Pommerening, B., Chaussod, R. and Brookes, P. C. (1990). Measurement of soil microbial biomass $\mathrm{C}$ by fumigation-extraction-an automated procedure. Soil Biology and Biochemistry, 22, 1167-1169.

Zarei, M., Sommer, M. and Stahr, K. (2001). Neoformed halloysite in podzols developed on the Bärhalde granite, southern black forest, germany, Proceedings of the 12th International Clay Conference. Bahia Blanca, Argentina, 227-234. 


\section{$\because$ Taylor \& Francis \\ Taylor \& Francis Group}

Journal... Chemistry and Ecology

Article ID... GCHE041010

\section{TO: CORRESPONDING AUTHOR}

\section{AUTHOR QUERIES - TO BE ANSWERED BY THE AUTHOR}

The following queries have arisen during the typesetting of your manuscript. Please answer the queries.

\begin{tabular}{|c|c|}
\hline Q1 & "these parameters were positively changed" - please clarify \\
\hline Q2 & $\begin{array}{l}\text { Sentence "Na-bentonite with smectites whose initial composition" } \\
\text { does not make sense. Please check }\end{array}$ \\
\hline Q3 & $\begin{array}{l}\text { Ditto sentence "Ca-bentonite and Na-bentonite are a higher } \\
\text { proportion of montmorillonite }(62-70 \%) \text { than for zeolite }(10 \%) \text { " }\end{array}$ \\
\hline $\mathrm{Q} 4$ & $\begin{array}{l}\text { "Ec/kEC" -- Please check italicization of variables. Also, should } \\
\text { there be a distinction between "EC" and "Ec"?, If so, please define } \\
\text { "EC" }\end{array}$ \\
\hline & \\
\hline & \\
\hline & \\
\hline & \\
\hline & \\
\hline & \\
\hline & \\
\hline & \\
\hline & \\
\hline & \\
\hline
\end{tabular}

Production Editorial Department, Taylor \& Francis Ltd.

4 Park Square, Milton Park, Abingdon OX14 4RN

Telephone: +44 (0) 1235828600

Facsimile: +44 (0) 1235829000 